\title{
The Impact of Toluene on the Performance of Anode-Supported Ni/YSZ SOFC Operated on Hydrogen and Biosyngas
}

\author{
Hossein Madi ${ }^{\mathrm{a}}$, Stefan Diethelm ${ }^{\mathrm{a}}$, Christian Ludwig ${ }^{\mathrm{b}}$ and Jan Van herle ${ }^{\mathrm{a}}$ \\ ${ }^{a}$ FUELMAT Group, Faculty of Engineering Sciences (STI), Ecole Polytechnique Fédérale de \\ Lausanne (EPFL), CH-1015 Lausanne, Switzerland \\ b PAUL SCHERRER INSTITUT, General Energy Research Department, Bioenergy and Catalysis \\ Laboratory, CH-5232 Villigen PSI
}

\begin{abstract}
This paper presents an experimental study of the impact of toluene on the performance of anode-supported (AS) Ni/YSZ SOFC operating at $\sim 800{ }^{\circ} \mathrm{C}$, $0.25 \mathrm{~A} / \mathrm{cm}^{2}$ fed with $\mathrm{H}_{2}$ and biosyngas. Toluene was added to the fuel stream and its concentration increased from tens to thousands of ppmv. Each poisoning test was followed by a recovery step. The main goal of this work is to define a concentration threshold of toluene as a model tar compound and to identify the degradation mechanism caused by this tar compound. Polarization behavior, IV and electrochemical impedance spectroscopy (EIS) were analyzed to evaluate the cell performance. A linear degradation is observed at concentrations above $1000 \mathrm{ppmv}$ for the cell which was fed with $\mathrm{H}_{2}$. The degradation was due to local $\mathrm{C}(\mathrm{s})$ deposition. By contrast, toluene even up to $3500 \mathrm{ppm}$ did not cause an increased degradation when the cell was fed with reformed biosyngas.
\end{abstract}

\section{Introduction}

Biomass is a resourceful, renewable, widely available and practically carbon neutral energy source. Thermo-chemical gasification of this abundantly available fuel generates a product gas, sometimes called also biosyngas, which can be used in high temperature fuel cells such as SOFCs. This product gas consists of hydrogen, carbon monoxide, carbon dioxide, methane, nitrogen and steam. Biosyngas may contain minor but a wide range of impurities such as sulfur compounds, aromatic hydrocarbons, hydrogen chloride etc., which can harm the durability of both the fuel cell (1) and the fuel processing units. The presence of contaminants in the product gas varies depends on the biomass substrate, the gasification agent and the type of gasifier (2).

The raw fuel gas should be filtered to a certain level, so that the product gas can be used as fuel for SOFCs but it is challenging to specify tolerance limits for impurities. The existence of such contaminants has lead to investigations on anode materials with different structures and compositions that may interact with the contaminants. Better understanding of the precise effect of each contaminant on the anode electro-catalyst is required. In particular, the experimental determination of the tolerance levels for chosen contaminants would be highly valuable for SOFC applications.

Tars are one of the major contaminant groups present in gasification syngas. In literature "tar" is used as a general expression for all higher hydrocarbon substances with more than 6 carbon atoms, condensable at room temperature, and with different properties. Depending on the gasification technology used, tar contents can be as high as several hundred $\mathrm{g} / \mathrm{Nm}^{3}$ for updraft gasifiers, however they are less present with fluidized bed and downdraft gasifiers, $15 \mathrm{~g} / \mathrm{Nm}^{3}$ and less than $2 \mathrm{~g} / \mathrm{Nm}^{3}$, respectively (3). Their composition is highly dependent on the reaction conditions, especially temperature, during the gasification process (4). A typical composition of biomass gasification tars is 
benzene (37.9 wt\%), toluene (14.3 wt\%), other one-ring aromatic hydrocarbons (13.9 wt $\%$ ), naphthalene $(9.6 \mathrm{wt} \%)$, the remainder being other two-, three- or four-ring aromatic hydrocarbons (4).

In SOFC, the primary effect of tars in the fuel stream is the formation of solid carbon on the anode, especially on the nickel catalyst. Carbon deposition can result in catalyst deactivation by blocking of the active sites, plugging of the micro- and macro-pores, and build-up of carbon filaments that could destroy the support of the catalyst. It has been reported that carbon deposition can occur on the active sites of the anode material and as its consequence rapid and irreversible deactivation is expected (5). Carbon deposits can lead to mechanical stress and finally break-down of the cells as their thermal expansion coefficient is different from the one of the ceramic/metal composition of the anode (6). Carbon deposition effects are strongly dependent on operating parameters of the cells. It is favored especially at low steam-to-carbon ratios (7) and low current, because high steam and/or oxygen content will lead to oxidation of the carbon and thus consume the deposit.

In this study, toluene was chosen as the model tar compound since (i) lighter aromatic tars are more difficult to remove than heavier ones (8) and (ii) research showed that the order of reactivity of a single-ring aromatic tar is much superior to that of two- and higher ring aromatics such as pyrene and naphthalene (9). The effect of toluene on the performance of anode-supported Ni/YSZ SOFC fed with hydrogen and reformed biosyngas are compared. The main objective is to evaluate the impact of toluene from tens of $\mathrm{ppm}$ to thousands ppm on the anode performance and durability at $800^{\circ} \mathrm{C}$ and $0.25 \mathrm{~A} / \mathrm{cm}^{2}$.

\section{Experimental}

In this study, a commercial Ni/YSZ anode-supported SOFC, with active cathode area of $8 \mathrm{~cm}^{2}$, produced by TOPSOE Fuel Cell was used. A test station has been developed to evaluate the carbon deposition characteristics of artificially added biomass gasification tars on SOFCs. A housing was developed and used to mount the cell in a furnace as described elsewhere (10). Liquid toluene was injected into a home-built evaporator (set to $140^{\circ} \mathrm{C}$ ) using a syringe pump. Deionised water was fed using a peristaltic pump into a second temperature-controlled evaporator, to adjust the steam addition. Two experiments were performed with different fuels (see Figure 1). The total fuel flow rate was held at $100 \mathrm{sccm}$ (standard cubic centimetres per minute). Synthetic air $79 \% \mathrm{~N}_{2}$ with $21 \% \mathrm{O}_{2}$ was used at the cathode side with a flow rate of $250 \mathrm{sccm}$. The anode fuel transfer lines were heated to prevent water condensation between the evaporator and furnace. Thermocouples (K-type) were used to monitor temperatures of evaporator, transfer lines and oven.

\section{Electrochemical Measurements}

The cell was heated at a rate of $100{ }^{\circ} \mathrm{C} /$ hour up to $800^{\circ} \mathrm{C}$. During the heating phase, the anode and cathode were provided with $100 \mathrm{sccm}$ of $\mathrm{Ar}$ and $250 \mathrm{sccm}$ of synthetic air, respectively. Once the furnace temperature reached $800^{\circ} \mathrm{C}$, the anode was reduced by providing a fuel flow containing $20 \%$ $\mathrm{H}_{2}$ in Ar for $2 \mathrm{~h}$. After this time, 50\% $\mathrm{H}_{2}$ with $50 \%$ Ar were fed for another $2 \mathrm{~h}$ in order to complete the reduction process. All impedance spectra were measured in galvanostatic mode with a frequency range from $0.02 \mathrm{~Hz}$ to $100 \mathrm{kHz}$ and a $20 \mathrm{~mA} \mathrm{AC}$ perturbation at $0.25 \mathrm{~A} / \mathrm{cm}^{2}$, using a Zennium electrochemical workstation (Zahner, Germany). EIS was performed every $25 \mathrm{~h}$, before and after every change in toluene concentration level.

Figure 1 shows the experimental plan and conditions for the two experiments. For the first experiment (Exp 1), the cell was fed with $\mathrm{H}_{2}$ and toluene was injected to the fuel stream when the 
voltage was stable. The concentration level of toluene was increased from 48 to $1960 \mathrm{ppm}$ and each poisoning test followed by a recovering step (no toluene in the fuel stream) for the duration of 25 hours. The cell in the second test (Exp. 2) was fed with reformed biosyngas made from a feed of $65 \%$ $\mathrm{H}_{2}$ with $25 \% \mathrm{CO}_{2}, 5 \% \mathrm{CO}$ and $5 \%$ steam.

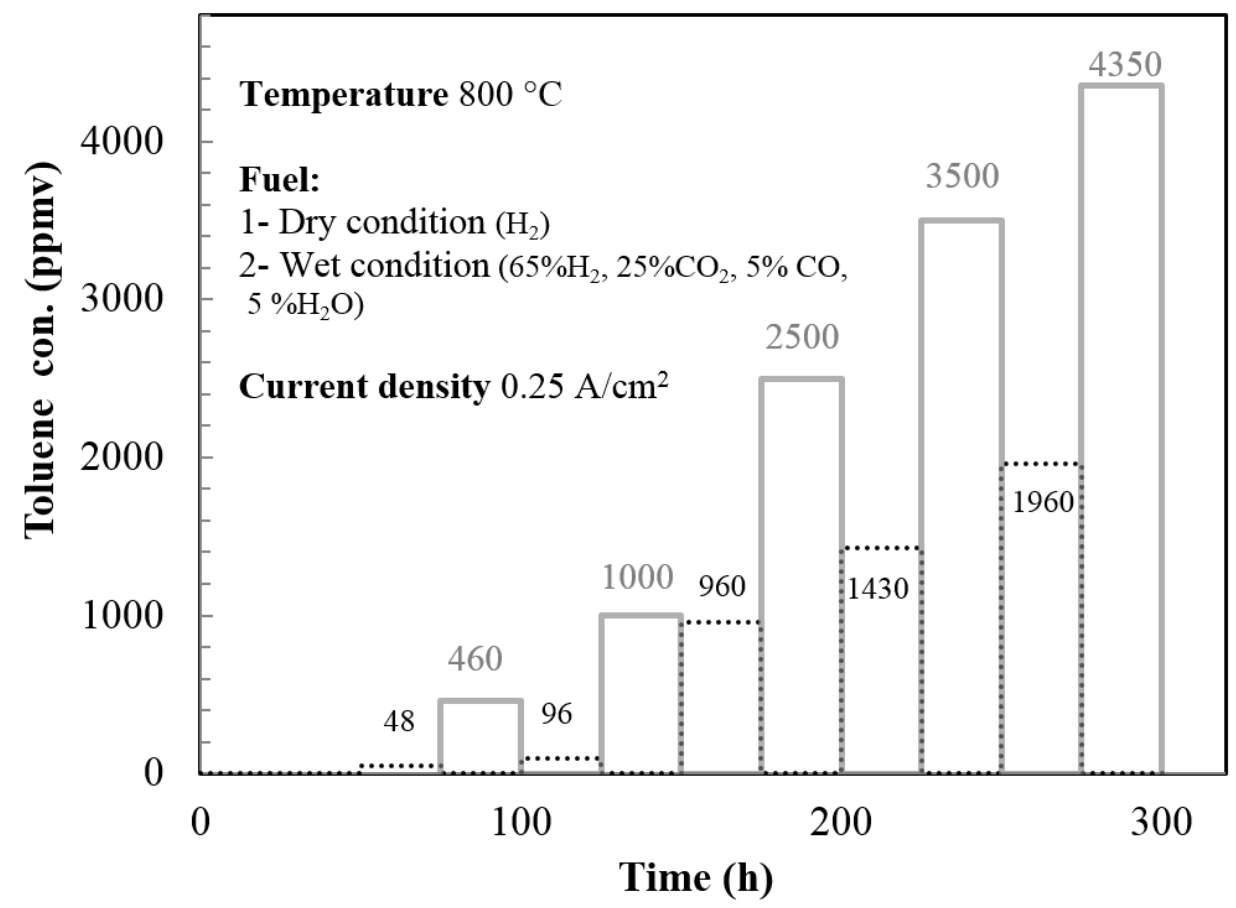

Figure 1. Experimental plan and the test conditions, dry fuel feed condition (black dotted lines) and wet fuel feed condition (gray full line)

\section{Results and Discussion}

\section{Operation on $\mathrm{H}_{2}($ Exp. 1)}

The cell was kept under polarization at $0.25 \mathrm{~A} / \mathrm{cm}^{2}$ at $750^{\circ} \mathrm{C}$ for a duration of $50 \mathrm{~h}$ to activate the cell. After voltage stabilization, $48 \mathrm{ppm}$ of toluene was added to the main fuel flow for a duration of $25 \mathrm{~h}$. In order to compare the degradation rate for each contaminant concentration, a regeneration step was necessary and achieved by stopping the flow of toluene. The recovery step was operated for $25 \mathrm{~h}$ as well. Figure 2 shows the performance of the cell at various concentrations of toluene. Degradation rates are compared in this figure for the concentration ranging from $48 \mathrm{ppm}$ up to almost $2000 \mathrm{ppm}$. The degradation trend (voltage decrease over time) is $4 \mathrm{mV} / 100 \mathrm{~h}$ for the first 150 hours of the test. Adding 960 and $1440 \mathrm{ppm}$ toluene increased the degradation rate to 20 and $61 \mathrm{mV} / 100 \mathrm{~h}$ respectively. A critical degradation is observed in the case of $1960 \mathrm{ppm}$. After $20 \mathrm{~h}$ of exposure to $1960 \mathrm{ppm}$, a severe drop in voltage occurred which was due to carbon formation at the fuel inlet and blockage of the line. 


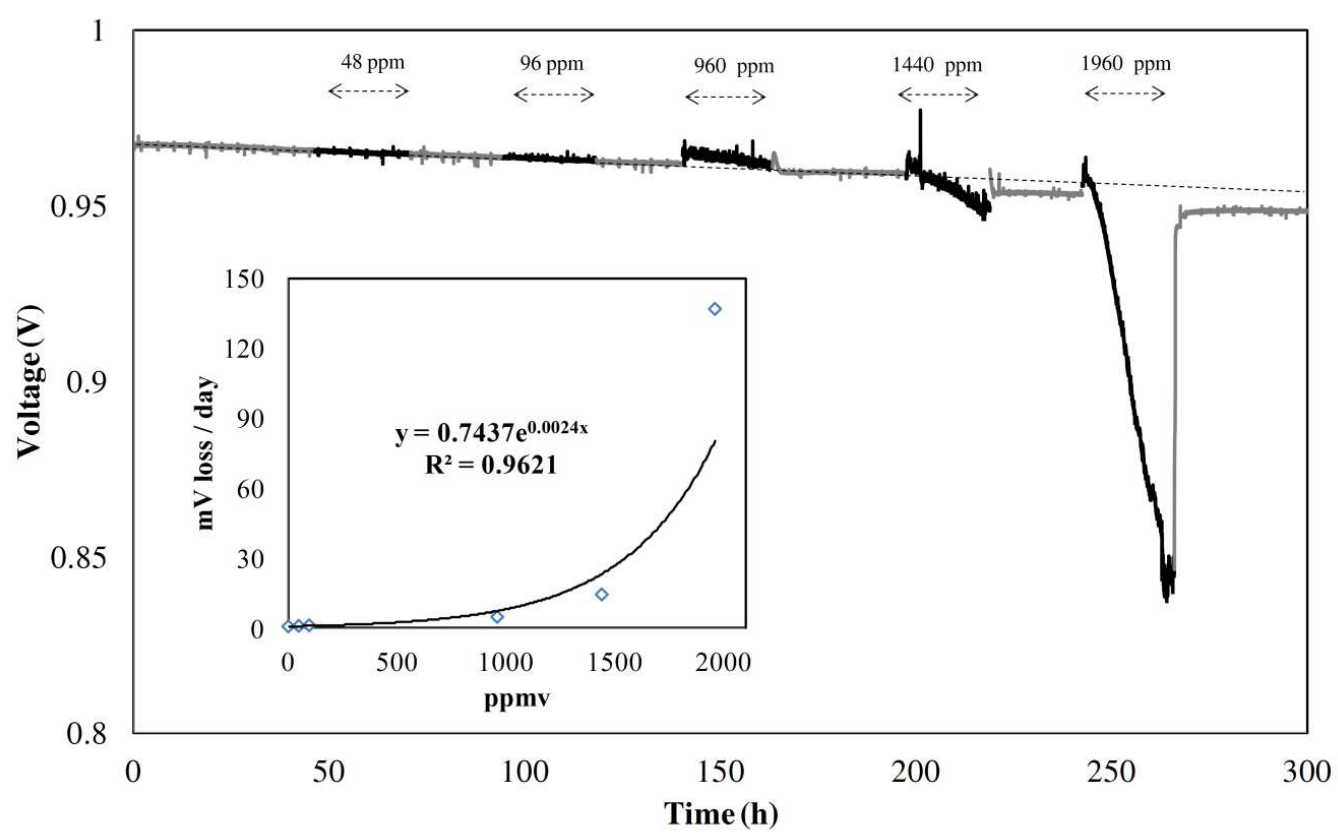

Figure 2. Overview of cell performance and degradation caused by toluene (Exp. 1 operation on $\mathrm{H}_{2}$ ). Black and gray colors are indicating condition with toluene and without toluene, respectively. The dashed line is the expected performance without toluene in the fuel.

Current-Voltage (IV). Consecutive IVs were performed at the beginning and end of a change in the conditions, i.e. before and after adding toluene, and after regeneration. Figure 3 shows IVs recorded after adding toluene. Area specific resistance (ASR) is increasing with increased tar concentration. In the case of $1960 \mathrm{ppm}$, there is a drop in OCV and the ASR much higher than other cases, as previously mentioned, due to the blocking of the fuel inlet. There was no change in OCV as the tar concentration increased. This does not indicate for deposited carbon. The concentration of the tar appears too low for any significant contribution in voltage increase.
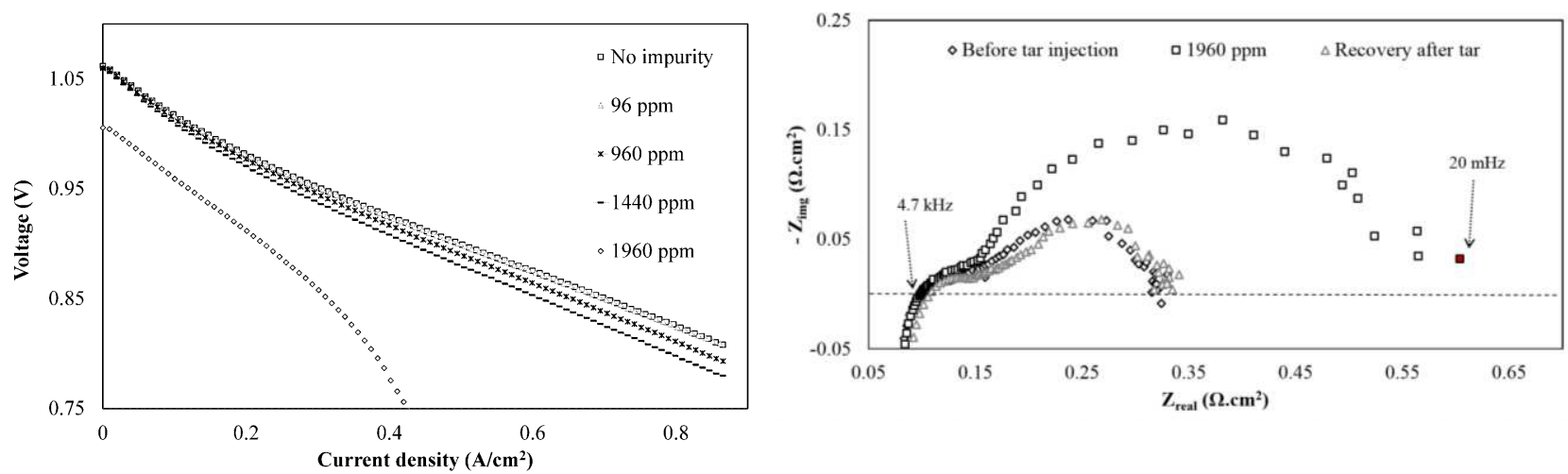

Figure 3. IV and EIS for the dry fuel condition test.

Impedance Spectroscopy can be used to characterize the impact of carbon deposits on cell performance. Impedance spectra were measured before tar loading and $25 \mathrm{~h}$ after exposure. EIS data confirm the IV curves, indicating no change in the high frequency ohmic intercept but a slight change in the low frequency polarization resistance. Figure 3 shows the evolution of impedance spectra measured for the case of exposure to $1960 \mathrm{ppm}$. The Nyquist plot (-Zimg vs. Zreal) shows two main depressed arcs, which are overlapping. Exposure to toluene enlarges the low frequency arc which 
indicates deposits due to toluene block catalytic active sites. Stopping the impurity flow restored the polarization resistance to its value prior introducing toluene to the fuel.

Recovery of the cell was examined for the different exposure steps to toluene. The degradation rate during the recovery phase stayed constant $(-0.04 \mathrm{mV} / \mathrm{h})$ until $200 \mathrm{~h}$ (before adding $1440 \mathrm{ppm}$ ), as shown with the dashed line in Figure 2. Switching to toluene-free $\mathrm{H}_{2}$ after the $1440 \mathrm{ppm}$ and 1960 ppm exposure steps, shows lower voltages than expected. EIS and IV results are not shown here but confirmed incomplete recovery of the cell was achieved for these cases. Hence, exposure to higher amounts of toluene can irreversibly alter the anode performance. It is interesting to mention that the degradation rate during the recovery phase after both $1440 \mathrm{ppm}$ and $1960 \mathrm{ppm}$ exposure steps is only $-0.02 \mathrm{mV} / \mathrm{h}$. This is not in contradiction with the existence of deposited carbon, as carbon deposits can enhance the anode conductivity leading to a temporary increase in performance (11). Carbon removal in this case is due to the direct reaction of carbon with oxygen ions (eq. 1). Carbon in this case needs to be located near the three phase boundary (TPB) lines to generate electrical current.

$$
\mathrm{C}+\mathrm{O}^{2-} \rightarrow \mathrm{CO}+2^{\mathrm{e}-} \quad \Delta H^{0}=-111 \mathrm{~kJ} \mathrm{~mol}^{-1}
$$

\section{Operation on Biosyngas (Exp. 2)}

Following the anode reduction, the cell was fed with $\mathrm{H}_{2}$ under $0.25 \mathrm{~A} / \mathrm{cm}^{2}$ at $800^{\circ} \mathrm{C}$ for a duration of 50 hours to ensure that the anode surface is carbon-free. Afterwards the fuel feed was switched to reformed biosyngas and operated for 25 hours under tar-free condition as shown in Figure 1. As no degradation was observed with low concentrations of toluene in the previous test, tar loading was started at a 10-fold concentration in this test. Figure 4 shows cell voltage over time for the case of 460 ppm, $1500 \mathrm{ppm}$ and $4350 \mathrm{ppm}$ exposure, corresponding to 1.87, 6.08 and $17.65 \mathrm{~g} / \mathrm{m}^{3}$ respectively of toluene in the fuel. Further intermediate exposure steps (not shown as V-t in Fig. 4) corresponded to the addition of $1000 \mathrm{ppm}, 2500 \mathrm{ppm}$ and $3500 \mathrm{ppm}$. No significant degradation was observed at concentrations lower than $3500 \mathrm{ppm}\left(14.2 \mathrm{~g} / \mathrm{Nm}^{3}\right)$.

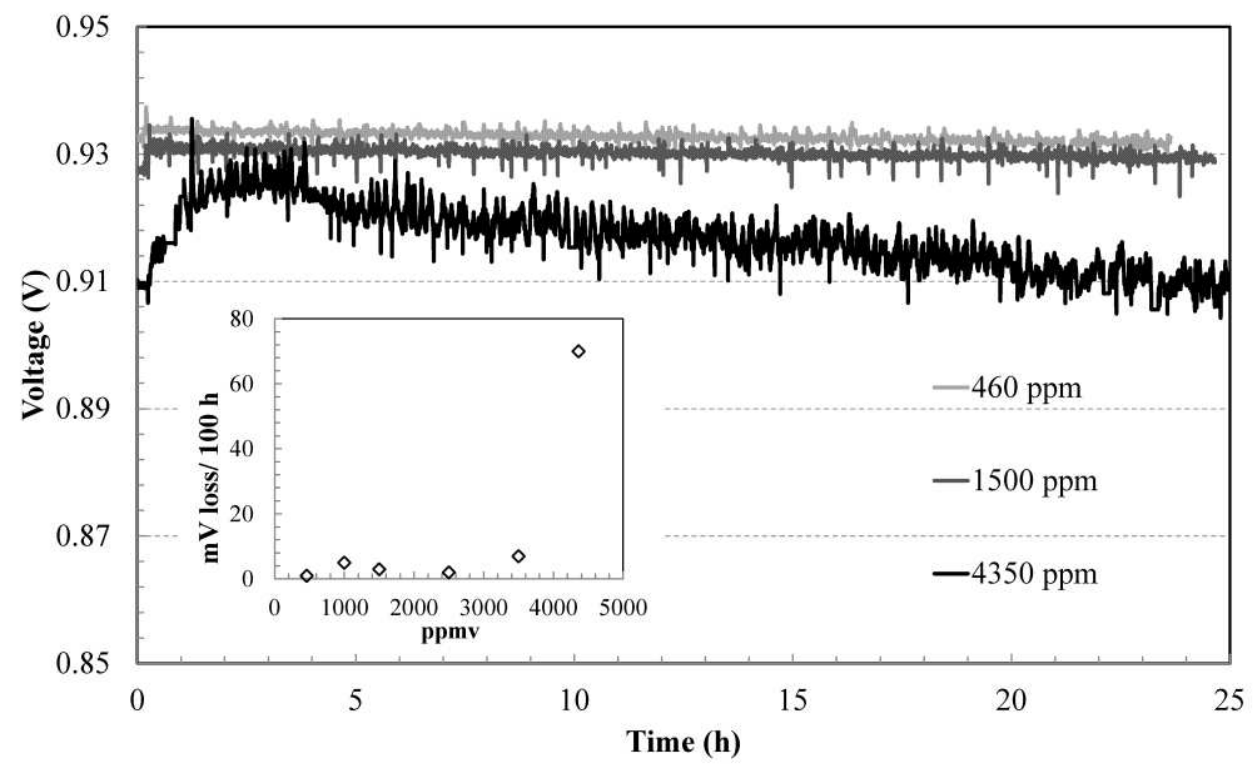

Figure 4. Polarization over time for the wet fuel condition test $\left(800^{\circ} \mathrm{C}, 0.25 \mathrm{~A} / \mathrm{cm}^{2}\right)$. Degradation rate for different levels of toluene is compared. 
Toluene is expected to partly reform with $\mathrm{H}_{2} \mathrm{O}$ on the nickel catalyst (steam reforming, eq. 2) or with $\mathrm{CO}_{2}$ (dry reforming, eq. 3). $\mathrm{H}_{2}$ and $\mathrm{CO}$ are produced due to these reforming reactions, therefore providing more fuel at the anode which consequently leads to an increased open circuit voltage (OCV). Assuming conversion by reforming of $1000 \mathrm{ppm}$ of toluene $(0.1 \%)$ would raise the $\mathrm{H}_{2} / \mathrm{CO}$ concentration by $1.8 \%$, making the effect non-negligible. In this experiment, cell operation at OCV is avoided due to possible anode delamination from the electrolyte and irreversible degradation (12). The initial increase in cell voltage is shown in Figure 5 (left). Data in this figure has been normalized for a better comparison of increase in voltage. This increase in voltage occurs during a short period of time.

$$
\begin{array}{lll}
\mathrm{C}_{7} \mathrm{H}_{8}+7 \mathrm{H}_{2} \mathrm{O} \rightarrow 7 \mathrm{CO}+11 \mathrm{H}_{2} & \Delta H^{0}=869 \mathrm{~kJ} \mathrm{~mol}^{-1} & {[2]} \\
\mathrm{C}_{7} \mathrm{H}_{8}+7 \mathrm{CO}_{2} \rightarrow 14 \mathrm{CO}+4 \mathrm{H}_{2} & \Delta H^{0}=1157 \mathrm{~kJ} \mathrm{~mol}^{-1}
\end{array}
$$

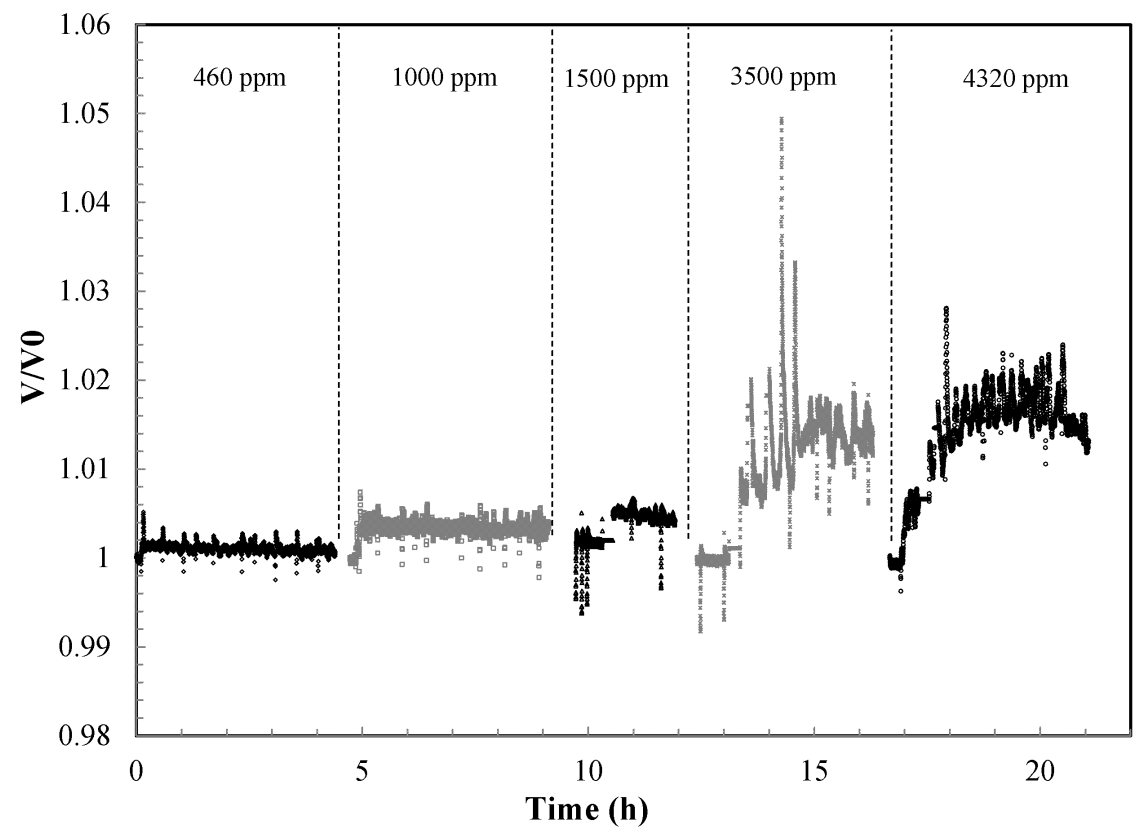

Figure 5. Initial increase in the cell voltage for different concentration of toluene (normalized values). The time of injection is labeled 0 .

Similar to the previous test, consecutive IVs and EIS were performed before and after changing the toluene concentration and also after regeneration. Figure 5 shows IVs recorded for different concentrations of toluene. Increasing the concentration leads to an increase in ASR. A reversible degradation was observed (data regarding to the recoveries is not shown here). 

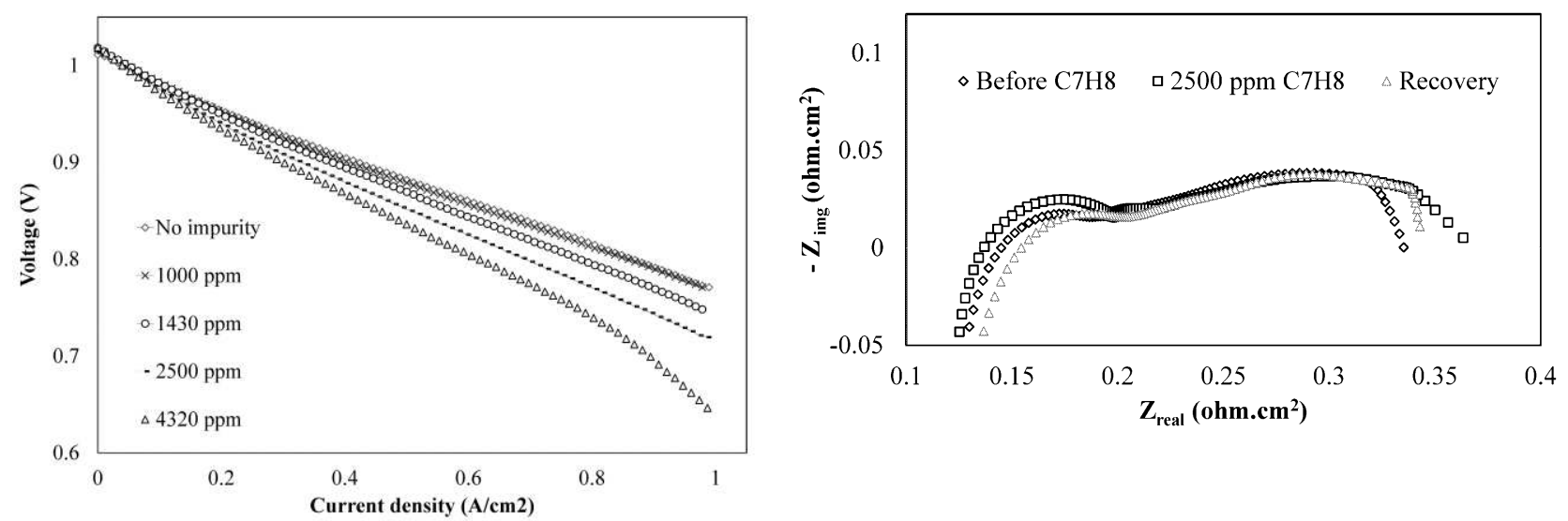

Figure 6. IV and EIS for the wet fuel condition test. Some of the data are not shown here for better reading.

Figure 7 shows the AS cells and Ni mesh current collector (middle) that were used for the experiments. The central parts of the cells are damaged and the Ni mesh current collector is partly disintegrated. This process is also known as metal dusting or dry corrosion. Metal dusting comprises the disintegration of bulk metal into metal particles at high temperatures $\left(300-850^{\circ} \mathrm{C}\right)$ in environments that are supersaturated with carbon. The dusting mechanism (13) is as follows:

1- initially carbon deposits (due to exposure to toluene) on the metal surface,

2- dissolution of the carbon into the bulk of the metal.

3- precipitation of carbon as a graphite fiber within the metal whereby the metal mechanically breaks up.
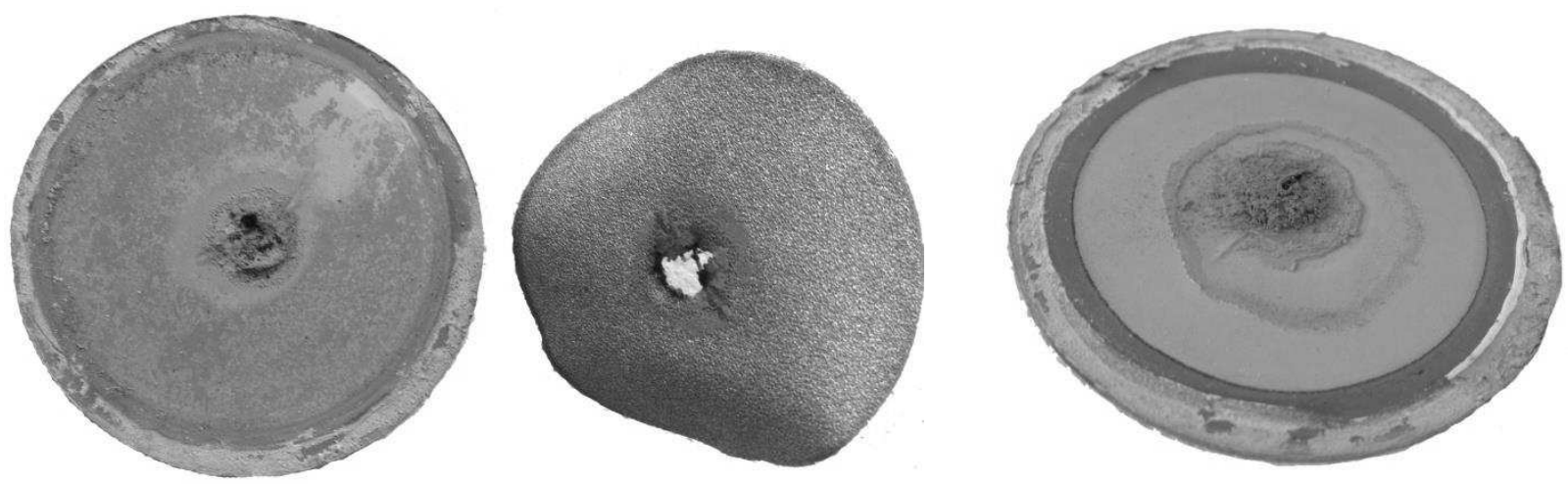

Figure 7. (left to right) Anode-supported cell after operation for $350 \mathrm{~h}$ under $\mathrm{H}_{2}$ plus toluene, $\mathrm{Ni}$ mesh current collector used at the anode side after the test, operation under reformed biogas, respectively.

\section{Conclusion}

The impact of a tar (toluene as a model compound), on the performance of AS Ni/YSZ SOFC fed with different fuels ( $\mathrm{H}_{2}$ and biosyngas) were studied. The polarization behavior, current-voltage and electrochemical impedance were measured to analyze the performance evolution. Results show that degradation due to exposure to tar compounds highly depends on the fuel composition. A linear degradation is observed at concentrations above $1000 \mathrm{ppmv}$ for a feed with only $\mathrm{H}_{2}$. In contrast, 
toluene even up to $3500 \mathrm{ppm}$ (for exposure durations of a day) did not cause significant added degradation when the cell was fed with biosyngas.

\section{Acknowledgments}

The research leading to these results has received funding from the Competence Center Energy and Mobility (CCEM), Woodgas-SOFC II and the European Union's Seventh Framework Program (FP7/2007-2013) for the Fuel Cells and Hydrogen Joint Technology Initiative under grant agreement number 278798 'SOFCOM'.

\section{References}

1. K. Sasaki et al., J. Power Sources, 196, 9130-9140 (2011).

2. P. V. Aravind and W. de Jong, Prog. Energy Combust. Sci., 38, 737-764 (2012).

3. D. J. Stevens, Hot Gas Conditioning: Recent Progress with Larger-scale Biomass Gasification Systems, (2001).

4. T. A. Milne and R. J. Evans, Biomass gasifier “'tars"”: their nature, formation, and conversion., (1998) http://www.nrel.gov/docs/fy99osti/25357.pdf.

5. J.-H. Koh, Y.-S. Yoo, J.-W. Park, and H. C. Lim, Solid State Ion., 149, 157-166 (2002).

6. J. R. Rostrup-Nielsen, J. Sehested, and J. K. Nørskov, in B.-A. in Catalysis, Editor, vol. 47, p. 65139, Academic Press (2002) http://www.sciencedirect.com/science/article/pii/S036005640247006X.

7. H. Madi, S. Diethelm, J. V. Herle, and N. Petigny, ECS Trans., 57, 1517-1525 (2013).

8. T. Namioka, T. Naruse, and R. Yamane, Int. J. Hydrog. Energy, 36, 5581-5588 (2011).

9. R. Coll, J. Salvadó, X. Farriol, and D. Montané, Fuel Process. Technol., 74, 19-31 (2001).

10. H. Madi et al., J. Power Sources, 279, 460-471 (2015).

11. R. J. Gorte, J. M. Vohs, and S. McIntosh, Solid State Ion., 175, 1-6 (2004).

12. V. Alzate-Restrepo and J. M. Hill, J. Power Sources, 195, 1344-1351.

13. C. h. Toh, P. r. Munroe, D. j. Young, and K. Foger, Mater. High Temp., 20, 129-136 (2003). 